\title{
Metabolism of 1,8-Cineole by a Rhodococcus Species: Ring Cleavage Reactions
}

\author{
By D. ROGER WILLIAMS, PETER W. TRUDGILL*AND \\ DA VID G. TAYLOR \\ Department of Biochemistry, University College of Wales, Aberystwyth SY23 3DD, UK
}

(Received 30 November 1988; revised 23 March 1989; accepted 7 April 1989)

\begin{abstract}
A Rhodococcus sp. (strain $\mathrm{C} 1$ ) was isolated by elective culture with 1,8-cineole as sole carbon source. 6-endo-Hydroxycineole and 6-oxocineole accumulated transiently during the latter part of the exponential growth phase and, together with 1,8-cineole, were oxidized rapidly by $1,8-$ cineole-grown cells. Although a putative 1,8-cineole monooxygenase was not detected in cellfree systems an induced 6-endo-hydroxycineole dehydrogenase and an induced NADPH-linked 6-oxocineole oxygenase were readily demonstrated. The lactone 5,5-dimethyl-4-(3'-oxobutyl)4,5-dihydrofuran-2(3H)-one was isolated from oxygenation reactions with 6-oxocineole as substrate. This was not the immediate product of oxygenation but resulted from non-enzymic lactonization of the ring cleavage intermediate 3-(1-hydroxy-1-methylethyl)-6-oxoheptanoic acid during extraction procedures. 2,5-Diketocamphane 1,2-monooxygenase purified from ( + camphor-grown Pseudomonas putida ATCC 17453 was also able to utilize 6-oxocineole as a substrate with formation of the same isolated product. The established oxygen-insertion specificity of this enzyme coupled with an unequivocal absence of esterase activity allowed the nature of the oxygen insertion into 6-oxocineole by the enzyme from Rhodococcus $\mathrm{Cl}$ to be inferred and a reaction sequence for cleavage of both rings of 1,8-cineole to be proposed. It provides an explanation for the reported isolation of $(R)-5,5$-dimethyl-4-(3'-oxobutyl)-4,5dihydrofuran-2(3H)-one from culture media of Pseudomonas flava grown with 1,8-cineole.
\end{abstract}

\section{INTRODUCTION}

Although the degradation of cyclic monoterpenes by bacteria growing with them as sole carbon sources has been studied for more than 25 years the ring cleavage reactions are understood for a very limited number of compounds and in no instance has the complete pathway to central metabolites been fully documented. Degradation of naturally occurring ( + camphor is the most thoroughly understood and involves an initial hydroxylation at carbon- 5 by Pseudomonas putida ATCC 17453 (Katagiri et al., 1968) or at carbon-6 by a Rhodococcus sp. (Chapman et al., 1966). In the case of $P$. putida cleavage of the two carbocyclic rings is catalysed by discrete 'Baeyer-Villiger' monooxygenases (Ougham et al., 1983; Taylor \& Trudgill, 1986). Although the ring cleavage product formed by the Rhodococcus sp. has been unequivocally identified the cleavage reactions have not been investigated in detail. In neither case have the post-cleavage reactions, leading to central metabolites, been established.

Degradation of the bicyclic hydrocarbon $\alpha$-pinene has also attracted significant attention and at least two distinct cleavage pathways have been described. One of these almost certainly involves initial cleavage of the four-membered carbon ring with the formation of the monocyclic monoterpene skeleton and integration of this into a proposed pathway for limonene degradation (Shukla et al., 1968) while the other is quite novel. Initial monooxygenation forms $\alpha$-pinene epoxide (Best et al., 1987) and ring cleavage in both Nocardia and some Pseudomonas spp. is mediated by $\alpha$-pinene oxide lyase (EC 4.99.-.-) which catalyses the concerted cleavage of all three rings without the requirement for any additional non-protein components (Griffiths et al., $1987 a, b)$. 


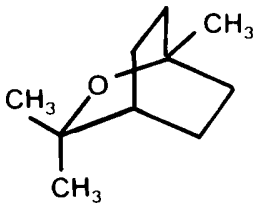

A

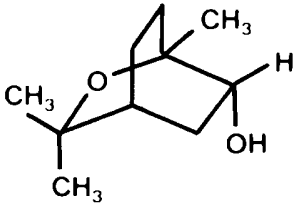

B

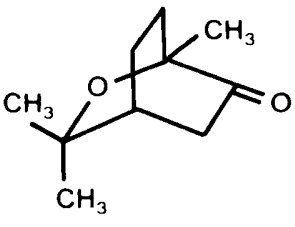

C

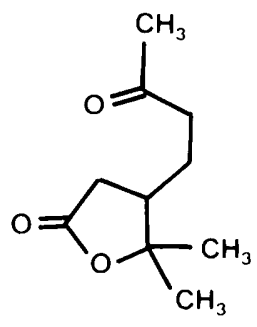

G

Fig. 1. The structure of 1,8-cineole and relevant reported metabolites. A, 1,8-cineole; B, 2-endohydroxycineole; C, 2-oxocineole; G, (R)-5,5-dimethyl-4-(3'-oxobutyl)-4,5-dihydrofuran-2(3H)-one.

There is good evidence that Pseudomonas spp., capable of utilizing the monocyclic monoterpene limonene as sole carbon source, degrade it by initial oxidation of a methyl group (carbon-7) to carboxyl followed by a $\beta$-oxidation cycle which achieves ring cleavage (Dhavalikar \& Bhattacharyya, 1966; Dhavalikar et al., 1966) although, once again, the route to central metabolites is obscure.

1,3,3-Trimethyl-2-oxabicyclo(2,2,2)octane [1,8-cineole] is a component of many essential oils and is the dominant component of the oil from leaves of Eucalyptus radiata var. Australiana (Nishimura et al., 1982). It is of particular interest in that while its carbocyclic skeleton is that of the monocylic monoterpenes the additional structural complication of a 1,8-ether linkage turns it into a bicyclic compound. Reports of 1,8-cineole metabolism are rudimentary, although analytically thorough, and include the isolation of $(1 S, 4 R, 6 R)-1,3,3$-trimethyl-2-oxabicyclo$(2,2,2)$ octan-6-ol [2-endo-hydroxycineole], $(1 S, 4 R, 6 S)$-1,3,3-trimethyl-2-oxabicyclo(2,2,2)octan6-ol [2-exo-hydroxycineole], $(1 S, 4 R)$-1,3,3-trimethyl-2-oxabicyclo(2,2,2)octan-6-one [2-oxocineole] and the lactone $(R)-5,5$-dimethyl-4-(3'-oxobutyl)-4,5-dihydrofuran-2(3H)-one from the culture medium of a strain of Pseudomonas flava isolated by elective culture with, and grown upon, 1,8-cineole as sole carbon source (MacRae et al., 1979; Carman et al., 1986) (Fig. 1) and the formation of the analogous C-3-substituted 1,8-cineole derivatives by broth-grown Aspergillus niger (Nishimura et al., 1982). It should be noted that strict application of chemical nomenclature rules does not allow the use of endo and exo in the $(2,2,2)$ bicyclo system. In common with other authors in this field (MacRae et al., 1979) we have designated compound B as the endo isomer because the hydroxyl substitution is on the opposite side of the reference plane from the lowest priority bridge. We have also made use of the ring numbering system consistent with the trivial name 1,8-cineole. In this paper we describe the isolation of a Rhodococcus sp. capable of growth with 1,8-cineole as sole carbon source, identify two enzymes involved in the initial stages of oxidation, and propose a reaction sequence for the concerted cleavage of the carbocyclic ring and the ether linkage.

A preliminary report of a section of this work has already appeared (Taylor \& Trudgill, 1988).

\section{METHODS}

Bacterial strains and culture conditions. Pseudomonas putida ATCC 17453 was obtained from the American Type Culture Collection. Rhodococcus sp. strain $\mathrm{C} 1$ was isolated from soil obtained from beneath a Eucalyptus sp. growing on the College campus at Aberystwyth. Stock cultures were grown on nutrient agar (Oxoid) at $30^{\circ} \mathrm{C}$, stored at $3{ }^{\circ} \mathrm{C}$ and subcultured at regular intervals. For experimental purposes $P$. putida was grown on $(+)$ camphor as previously described (Taylor \& Trudgill, 1986) and Rhodococcus $\mathrm{Cl}$ was grown at $30^{\circ} \mathrm{C}$ in a medium that contained $\left(\mathrm{g} \mathrm{l}^{-1}\right): \mathrm{KH}_{2} \mathrm{PO}_{4}, 2 ; \mathrm{Na}_{2} \mathrm{HPO}_{4}, 4 ;\left(\mathrm{NH}_{4}\right)_{2} \mathrm{SO}_{4}, 1$. Trace element solution (Rosenberger \& Elsden, $1960)$ was added at $0.4 \%(\mathrm{v} / \mathrm{v})$ before the medium was sterilized by autoclaving. When required sodium succinate hexahydrate $\left(4.6 \mathrm{~g} \mathrm{l}^{-1}\right)$ was added prior to autoclaving. Sterile 1,8-cineole $\left(1 \mathrm{~g} \mathrm{l}^{-1}\right)$ was added aseptically to the autoclaved basal medium. For growth with 1,8-cineole a $20 \mathrm{ml}$ starter culture, with succinate as carbon source, was inoculated from a slope and grown on a gyratory shaker at 150 r.p.m. and $30^{\circ} \mathrm{C}$ for $48 \mathrm{~h}$. Subsequently $10 \%(\mathrm{v} / \mathrm{v})$ inocula were transferred to $100 \mathrm{ml}$ and $900 \mathrm{ml}$ volumes of media, with 1,8-cineole as substrate, in $250 \mathrm{ml}$ and 21 
Erlenmeyer flasks respectively and grown for 18-24 h. Cells were then either harvested for experimental purposes $\left(10000 \mathrm{~g}, 30 \mathrm{~min}, 4^{\circ} \mathrm{C}\right)$ or used to inoculate 91 of 1,8 -cineole medium in a New Brunswick Microferm laboratory fermenter which was stirred at 500 r.p.m. and aerated by the passage of sterile air at the rate of $11 \mathrm{~min}^{-1}$. After 15$18 \mathrm{~h}$ growth the culture was either harvested in a continuous flow centrifuge (Alfa Laval) at a rate of 0.4 $0.51 \mathrm{~min}^{-1}$ or used to inoculate $30 \mathrm{l}$ of medium in a 501 plastic vessel adapted to fit the fermenter which was stirred at 600 r.p.m., aerated by the passage of sterile air at $61 \mathrm{~min}^{-1}$, and the culture harvested after $\simeq 10 \mathrm{~h}$ growth. Cell pellets were routinely resuspended in an equal volume of $42 \mathrm{mM}-\mathrm{KH}_{2} \mathrm{PO}_{4} / \mathrm{Na}_{2} \mathrm{HPO}_{4}$ buffer $(\mathrm{pH} 7 \cdot 1)$ and either used immediately or stored at $-20^{\circ} \mathrm{C}$ until required.

Preparation of cell extracts. Washed resuspended cells were disrupted by either (a) passage through a French pressure cell with a pressure difference at the orifice of $138 \mathrm{MPa},(b)$ passage of the frozen cell paste through a Hughes press at $-15^{\circ} \mathrm{C}$ or $(c)$ by sonication of $10 \mathrm{ml}$ samples in an ice-bath for two $30 \mathrm{~s}$ periods, with a $1 \mathrm{~min}$ cooling interval, at an amplitude of $18-20 \mu \mathrm{m}$ (MSE Soniprep). Broken cell suspensions were incubated with approximately $0.5 \mathrm{mg}$ of DNAase (EC 3.1 .21 . 1) per $10 \mathrm{ml}$ for $15 \mathrm{~min}$ at $4{ }^{\circ} \mathrm{C}$ and then centrifuged at $27000 \mathrm{~g}$ and $4{ }^{\circ} \mathrm{C}$ for $45 \mathrm{~min}$ to remove cell debris. The crude cell extract was decanted and stored at $-20^{\circ} \mathrm{C}$ until required. Membrane preparations were obtained by centrifugation of crude cell extract at $100000 \mathrm{~g}$ and $4{ }^{\circ} \mathrm{C}$ for $60 \mathrm{~min}$. The pink gelatinous pellet was resuspended in $42 \mathrm{mM}-\mathrm{KH}_{2} \mathrm{PO}_{4} / \mathrm{Na}_{2} \mathrm{HPO}_{4}$ buffer (pH 7.1), centrifuged as above for a further $60 \mathrm{~min}$ and again resuspended in the same phosphate buffer before use.

Protein measurement. The biuret assay, as modified by Gornall et al. (1949), was used routinely for the estimation of protein in solution. A crude estimate of the protein content of column fractions was made by measuring absorbance at $280 \mathrm{~nm}$.

Measurement of oxygen uptake. Oxygen consumption by whole cell suspensions or crude cell extracts was measured either by conventional Warburg manometry or polarographically using an oxygen monitor (Yellow Springs Instrument Co.).

Extraction of metabolites. Bacteria were removed from culture media either by passage of small volumes $(<20 \mathrm{ml})$ through a membrane filter $(0.22 \mu \mathrm{m})$ or by continuous flow centrifugation of larger volumes (Alfa Laval). Neutral metabolites were extracted by shaking the aqueous medium with an equal volume of redistilled diethyl ether which was separated and dried over anhydrous $\mathrm{Na}_{2} \mathrm{SO}_{4}$. When necessary the diethyl ether was removed by rotary evaporation under vacuum. Acidic metabolites were similarly extracted into diethyl ether after first acidifying the aqueous medium to $\simeq \mathrm{pH} 1$ with $5 \mathrm{M}-\mathrm{HCl}$.

GLC analysis of metabolites. Samples $(1 \mu \mathrm{l})$ of diethyl ether extracts containing not more than $100 \mu \mathrm{g} \mathrm{ml} \mathrm{H}^{-1}$ of individual metabolites were analysed by GLC on a Carlo Erba HRGC 5300 instrument fitted with a WCOT fused silica CP-wax-52 CB capillary column $(0.32 \mathrm{~mm} \times 25 \mathrm{~m})$ and a flame ionization detector. Hydrogen was used as the carrier gas at $1.5 \mathrm{ml} \mathrm{min}^{-1}$. The temperature programme was $45-80^{\circ} \mathrm{C}$ at $25^{\circ} \mathrm{C} \mathrm{min}^{-1} ; 80-150^{\circ} \mathrm{C}$ at $3^{\circ} \mathrm{C} \min ^{-1} ; 150-245^{\circ} \mathrm{C}$ at $35^{\circ} \mathrm{C} \mathrm{min}^{-1}$. The final temperature was maintained for $10 \mathrm{~min}$.

GLC-MS analysis. GLC-mass spectral analyses were done on a $25 \mathrm{~m}$ polar BP20 fused silica capillary column programmed from $50^{\circ} \mathrm{C}(3 \mathrm{~min})$ to $250^{\circ} \mathrm{C}$ at $10^{\circ} \mathrm{C} \mathrm{min}-1$. Helium was used as the carrier gas at a flow rate of $2 \mathrm{ml} \mathrm{min}^{-1}$. Electron impact spectra were recorded on a VG $12 \mathrm{~F}$ mass spectrometer (VG Analytical) with a beam energy of $70 \mathrm{eV}$, source temperature of $150^{\circ} \mathrm{C}, 100 \mu \mathrm{A}$ emission and scan cycle time of $2.7 \mathrm{~s}$. Chemical ionization spectra were obtained with a VG $70 \mathrm{HSE}$ instrument using isobutane as the reagent gas at a source housing pressure of $2 \mathrm{~Pa}$ and $200 \mu \mathrm{A}$ emission.

NMR spectra. Proton nuclear magnetic resonance ( $\left.{ }^{1} \mathrm{H}-\mathrm{NMR}\right)$ spectra were recorded on a JOEL FX60Q Fourier transform spectrometer in $\mathrm{CDCl}_{3}$ at $60 \mathrm{MHz}$ with tetramethylsilane as internal standard.

Measurement of optical rotation. Optical rotations of isolated metabolites were measured in ethanolic solution with a $20 \mathrm{~mm}$ light-path cell in a Bendix NPL Automatic Polarimeter at $589.5 \mathrm{~nm}$ (sodium D line).

Estimation of lactones. The alkaline hydroxamate procedure of Cain (1961) was used for the detection and assay of lactones.

Measurement of changes in proton concentration. The consumption of protons in enzyme-catalysed reactions was followed in near-buffer-free aqueous reaction systems at $20^{\circ} \mathrm{C}$. The $\mathrm{pH}$ was maintained at a constant value by the controlled addition of $2 \mathrm{mM}-\mathrm{HCl}$ from a burette attached to an autotitrator (Pye-Unicam).

Enzyme units. All enzyme activities are expressed as $\mu \mathrm{mol}$ substrate used or product formed $\mathrm{min}^{-1}$. Unless otherwise stated all assays were done at $30^{\circ} \mathrm{C}$.

Enzyme assays. 2,5-Diketocamphane 1,2-monooxygenase was routinely assayed, using (+)-camphor as the substrate, either by measuring substrate-stimulated NADH oxidation spectrophotometrically or by following oxygen consumption polarographically. A typical reaction mixture contained, in a total volume of $3 \mathrm{ml}, 120 \mu \mathrm{mol}$ $\mathrm{KH}_{2} \mathrm{PO}_{4} / \mathrm{Na}_{2} \mathrm{HPO}_{4}$ buffer (pH 7.1), 0.4 $\mu \mathrm{mol} \mathrm{NADH}$ and $0.025-0.50$ units of enzyme. Reactions were initiated by the addition of $1 \mu \mathrm{mol}(+)$-camphor. 6-endo-Hydroxycineole dehydrogenase was assayed either $(a)$ by measuring substrate-stimulated $\mathrm{NAD}^{+}$reduction spectrophotometrically at $340 \mathrm{~nm}$ when $1 \mu \mathrm{mol} 6$-endohydroxycineole was added to a reaction mixture that contained, in a total voll me of $1 \mathrm{ml}, 80 \mu \mathrm{mol}$ glycine/ $\mathrm{NaOH}$ buffer or $\mathrm{H}_{3} \mathrm{PO}_{4} / \mathrm{Na}_{4} \mathrm{P}_{2} \mathrm{O}_{7}$ buffer (pH 10.5), $2 \mu \mathrm{mol} \mathrm{NAD}{ }^{+}$and $0 \cdot 01-0.25$ units of enzyme, or (b) by following the 
substrate-stimulated oxidation of NADH when $1 \mu \mathrm{mol}$ 6-oxocineole was added to a cuvette that typically contained in $1 \mathrm{ml}, 80 \mu \mathrm{mol} \mathrm{H}_{3} \mathrm{PO}_{4} / \mathrm{Na}_{4} \mathrm{P}_{2} \mathrm{O}_{7}$ buffer (pH 7.5), $0 \cdot 15 \mu \mathrm{mol} \mathrm{NADH}$ and $0 \cdot 01-0 \cdot 25$ units of enzyme. 6-Oxocineole oxygenase was assayed either by measuring substrate-stimulated NADPH oxidation spectrophotometrically or oxygen uptake polarographically. A typical reaction mixture contained, in a total volume of $3 \mathrm{ml}$, $250 \mu \mathrm{mol} \mathrm{H}_{3} \mathrm{PO}_{4} / \mathrm{Na}_{4} \mathrm{P}_{2} \mathrm{O}_{7}$ buffer ( $\mathrm{pH} 9$ ), 0.5-1 $\mu \mathrm{mol} \mathrm{NADPH}$ and 0.07-0.7 units of enzyme. Reactions were initiated by the addition of $2 \mu \mathrm{mol} 6$-oxocineole.

Enzyme purification. 2,5-Diketocamphane 1,2-monooxygenase was partially purified by $\left(\mathrm{NH}_{4}\right)_{2} \mathrm{SO}_{4}$ fractionation and anion exchange chromatography essentially as described previously (Taylor \& Trudgill, 1986). The final preparation was dialysed against $1 \mathrm{mM}-\mathrm{KH}_{2} \mathrm{PO}_{4} / \mathrm{Na}_{2} \mathrm{HPO}_{4}$ buffer $(\mathrm{pH} 7 \cdot 1)$ and stored at $-20^{\circ} \mathrm{C}$ until required.

Chemical synthesis. The lactone 5,5-dimethyl-4-(3'-oxobutyl)-4,5-dihydrofuran-2(3H)-one was prepared from $\alpha$-terpineol, essentially as described by MacRae et al. (1979) and recrystallized from diethyl ether. 3-(1-Hydroxy-1methylethyl)-6-oxoheptanoic acid was prepared as a $20 \mathrm{~mm}$ buffered solution from the lactone. The lactone $\left(20 \mathrm{mg}\right.$ ) was dissolved in $2 \mathrm{ml} 1 \mathrm{M}-\mathrm{NaOH}$ and incubated at $100^{\circ} \mathrm{C}$ for $20 \mathrm{~min}$. The solution was cooled on ice, $1 \mathrm{ml}$ $0 \cdot 1 \mathrm{M}$-Tris/ $\mathrm{HCl}$ buffer (pH 8) added and, after adjustment of the $\mathrm{pH}$ to 8 with $2 \mathrm{M}-\mathrm{HCl}$, made up to $5 \mathrm{ml}$ with $\mathrm{H}_{2} \mathrm{O}$ and stored at $-20^{\circ} \mathrm{C}$.

Sources of other chemicals. $\alpha$-Terpineol and magnesium monoperoxyphthalate were supplied by Aldrich. 1,8Cineole and (+)-camphor were supplied by Sigma. NAD ${ }^{+}$, NADP $^{+}$, NADH and NADPH were from Park Scientific. DEAE-Sephacel was supplied by Pharmacia, DEAE-cellulose (DE52) by Whatman and DNAase by Fluka. 2,5-Diketocamphane was a generous gift from Dr I. C. Gunsalus, Department of Biochemistry, University of Illinois, Champaign-Urbana, Illinois, USA. All other reagents were of high purity, the majority being of AnalaR grade from BDH.

\section{RESULTS}

\section{Identification of Rhodococcus sp. strain C1}

Strain $\mathrm{Cl}$ is a Gram-positive non-motile rod (average size $4.0 \times 1.3 \mu \mathrm{m}$ ) with limited mycelial development, rudimentary branching and early $(15 \mathrm{~h})$ fragmentation into rods and coccobacilli. Colonies on nutrient agar and glucose-nutrient agar $(72 \mathrm{~h})$ were soft butyrous, $3 \mathrm{~mm}$ diameter, coral-red, shiny and opaque with a crenate edge. The organism grew at temperatures up to $47^{\circ} \mathrm{C}$, was catalase and oxidase positive and an obligate aerobe. In sugar broths there was no acid production from glucose, sucrose or lactose. Tests for lecithinase, indole formation, starch hydrolysis, $\mathrm{H}_{2} \mathrm{~S}$ formation (cysteine agar) and the Voges-Proskauer and methyl red tests were all negative. Nitrate was reduced only to nitrite in peptone water, urease was produced on Christiensen's medium and the organism was sensitive to a wide range of antibiotics. These properties are consistent with the organism being a Rhodococcus sp. (Goodfellow, 1986).

\section{Growth of organism and metabolite accumulation}

1,8-Cineole. Rhodococcus $\mathrm{Cl}$ grew on 1,8-cineole in shake-flask culture with a doubling time of approximately $8 \mathrm{~h}$. GLC analysis of unconcentrated neutral diethyl ether extracts of culture media, taken throughout the growth phase, showed the transient accumulation of two compounds that reached maximum concentrations after about 16-17 h growth (Fig. 2). Yields were quantified (no correction for structure-related variation in flame-ionization detector response) by reference to $(+)$-camphor as the internal standard, added to the cell-free medium at a concentration of $40 \mu \mathrm{g} \mathrm{ml}^{-1}$ before diethyl ether extraction. No acidic metabolites were detected.

Sufficient quantities of the two metabolites for unequivocal identification and for use in metabolic studies were obtained by extraction of a $40 \mathrm{l}$ culture. The diethyl ether extract was dried, evaporated to a volume of $4 \mathrm{ml}$ under reduced pressure and stored at $-20^{\circ} \mathrm{C}$ for $72 \mathrm{~h}$. The copious crystalline white solid that had formed was filtered off, washed with cold dry diethyl ether, dried under vacuum and recrystallized from saturated solution in boiling diethyl ether. GLC analysis gave a single peak, retention time $12 \cdot 2 \mathrm{~min}$, m.p. $93-95^{\circ} \mathrm{C}$. Mass spectral analysis gave a molecular ion at $m / e 170(22 \%)$ with associated ions at $126(93 \%), 111(48 \%), 108(100 \%)$, $93(43 \%), 83(40 \%), 71(81 \%), 69(52 \%)$ and $43(77 \%)$ - a fragmentation pattern almost identical with that reported for the two isomers of 2-hydroxycineole (MacRae et al., 1979). The ${ }^{1} \mathrm{H}-\mathrm{NMR}$ spectrum $\left(\delta 3.53\right.$, broad multiplet that collapsed to a triplet on adding $\mathrm{D}_{2} \mathrm{O}, \mathrm{H} 6$, $J_{6,5 e n d o}=J_{6,5 e x o}=6 \mathrm{~Hz}$; three methyl groups at $\delta 1 \cdot 27,1 \cdot 20$ and $1 \cdot 10$ ) was also identical with that 


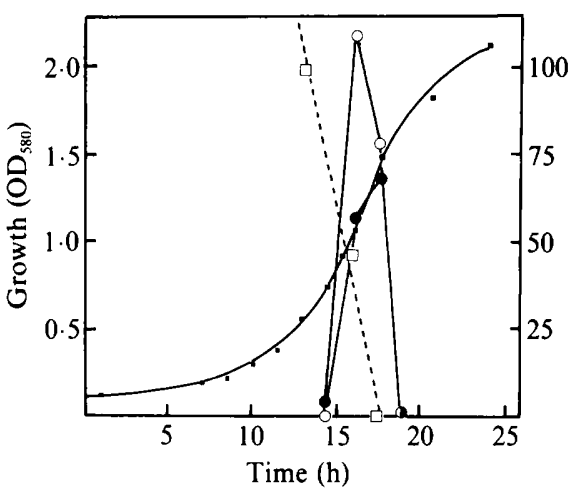

Fig. 2

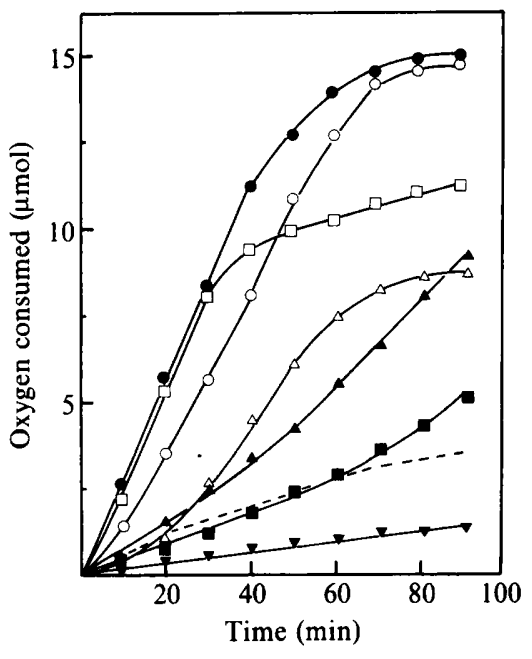

Fig. 3

Fig. 2. Transient accumulation of metabolites in the culture medium during growth of Rhodococcus $\mathbf{C l}$ on 1,8-cineole. $\square$, Growth $\left(\mathrm{OD}_{580}\right) ; \square, 1,8$-cineole; $\bigcirc$, 6-endo-hydroxycineole;, 6 -oxocineole.

Fig. 3. Oxidation of 1,8-cineole and putative catabolic intermediates by Rhodococcus $\mathrm{Cl}$. Warburg flasks contained, in a total volume of $2 \mathrm{ml}, 5 \mathrm{mg}$ dry wt of 1,8-cineole-grown Rhodococcus $\mathrm{Cl}$ and $80 \mu \mathrm{mol}$ phosphate buffer, $\mathrm{pH} 7 \cdot 1$. Reactions, at $30^{\circ} \mathrm{C}$, were started by the addition of substrates $(3 \mu \mathrm{mol})$ from side-arms. Centre wells contained $0.1 \mathrm{ml} 20 \%(\mathrm{w} / \mathrm{v}) \mathrm{KOH}$ and a roll of filter paper to facilitate absorption of $\mathrm{CO}_{2}$. O, 1,8-Cineole;, 6 -endo-hydroxycineole; $\square$, 6-oxocineole; $\nabla, 5,5$ dimethyl-4-(3'-oxobutyl)-4,5-dihydrofuran-2(3H)-one; $\square, 3$-(1-hydroxy-1-methylethyl)-6-oxoheptanoic acid; $\triangle$, levulinic acid; $\boldsymbol{\Delta}$, acetone. Endogenous respiration (---) has not been subtracted.

previously reported for 2-endo-hydroxycineole (MacRae et al., 1979). However, while MacRae et al. (1979) reported that 2-endo-hydroxycineole was laevorotatory, $[\alpha]_{\mathrm{D}}-26^{\circ}(c=0.2$ in ethanol), the accumulated metabolite was dextrorotatory, $[\alpha]_{D}+27 \cdot 5^{\circ}(c=0.2$ in ethanol). These results are only compatible with the compound being the optical isomer 6-endo-hydroxycineole.

The mother liquor was greatly enriched in the second, more volatile metabolite which was further purified, after removal of solvent, by chromatography on Brockmann activity III. alumina, developed with n-hexane. Removal of the eluting solvent left a soft white crystalline solid which was shown by GLC (retention time $11 \mathrm{~min}$ ) to be contaminated with traces of 6endo-hydroxycineole. The residual impurity was removed from a small sample of the compound by sublimation, in a closed vessel maintained at $55^{\circ} \mathrm{C}$, onto a cold finger. This gave $150 \mathrm{mg}$ of chromatographically pure material. This compound, m.p. $47-49^{\circ} \mathrm{C}$, reacted with acidic $2,4-$ dinitrophenylhydrazine reagent (Friedemann \& Haugen, 1943) to form a bright-orange insoluble 2,4-dinitrophenylhydrazone. Mass spectral analysis of the ketonic compound gave a spectrum almost identical with that previously reported (Nishimura et al., 1982) for 2-oxocineole with a molecular ion at $m / e 168(10 \%)$ and major associated ions at $140(21 \%), 111(7 \%), 97(9 \%)$, $82(100 \%), 69(17 \%), 67(14 \%)$ and $43(22 \%)$. The ${ }^{1} \mathrm{H}-\mathrm{NMR}$ spectrum $(\delta 2.92$ and 2.71 triplets, $\mathrm{H} 5$ exo and endo, $J_{5,5}=20 \mathrm{~Hz}, J_{5,4}=3 \mathrm{~Hz}$, three methyl groups at $1.40,1.25$ and 1.15$)$ also displayed all the diagnostic features attributable to 2-oxocineole (MacRae et al. 1979; Nishimura et al., 1982). However, although MacRae et al. (1979) reported that 2-oxocineole was dextrorotatory, $[\alpha]_{D}+70 \cdot 2^{\circ}$, the accumulated ketone was laevorotoatory, $[\alpha]_{D}-42 \cdot 5^{\circ}(c=0 \cdot 2$ in ethanol), again suggesting that the compound is predominantly the optical isomer 6-oxocineole.

Putative catabolic intermediates. In addition to growth with 1,8-cineole Rhodococcus $\mathrm{Cl}$ was also able to utilize 6-endo-hydroxycineole, 6-oxocineole, 3-(1-hydroxy-1-methylethyl)-6-oxoheptanoic acid, levulinic acid and acetone as sole carbon sources for growth. The synthetic lactone 5,5-dimethyl-4-(3'-oxobutyl)-4,5-dihydrofuran-2(3H)-one did not support growth. 
Oxidation of 1,8-cineole and related compounds by whole cells

Washed cell suspensions of 1,8-cineole-grown Rhodococcus $\mathrm{Cl}$ oxidized 1,8-cineole, 6-endohydroxycineole and 6-oxocineole rapidly with no significant lag period while levulinic acid, acetone and synthetic 3-(1-hydroxy-1-methylethyl)-6-oxoheptanoic acid were oxidized more slowly (Fig. 3). Succinate-grown cells did not oxidize any of these compounds significantly during the experimental period $(80 \mathrm{~min})$.

\section{Studies with subcellular systems}

1,8-Cineole as substrate. No enzyme-mediated transformation of 1,8-cineole was detected with subcellular systems obtained from cells disrupted in the Hughes press, in the French press or by ultrasonication whether or not reducing agents were included with the cell suspension. Crude cell crushes and membrane preparations were all inactive towards 1,8-cineole, irrespective of the buffer system, the electron donor employed, or the analytical method used.

6-endo-Hydroxycineole dehydrogenase. An $\mathrm{NAD}^{+}$-dependent enzyme, catalysing the dehydrogenation of 6-endo-hydroxycineole, was detected spectrophotometrically in extracts of 1,8cineole-grown cells. The $\mathrm{pH}$ optimum of the reaction was 10.5 and the product was identified as 6-oxocineole by GLC analysis and comparison with the authentic ketone. The reverse reaction, pH optimum 7.5 with 6-oxocineole as substrate and NADH as electron donor, yielded 6-endohydroxycineole exclusively. Some activity $(<10 \%)$ was also detected when NADPH was substituted as the electron donor but, again, only 6-endo-hydroxycineole was detected. Enzyme activity was negligible in extracts of succinate-grown cells (Table 1 ).

6-Oxocineole oxygenase. When crude cell extracts were incubated with 6-oxocineole and NADPH in the oxygen monitor a substrate-stimulated consumption of oxygen occurred. The induced enzyme responsible was distinguished from the low level of NADPH-linked 6-endohydroxycineole dehydrogenase activity by doing spectrophotometric assays at $\mathrm{pH} 9$; under these conditions the dehydrogenase activity was almost completely suppressed (Table 1). Oxygen monitor assays done in the presence of limited amounts of either 6-oxocineole or NADPH

Table 1. Properties of 6-endo-hydroxycineole dehydrogenase and 6-oxocineole oxygenase in extracts of Rhodococcus $\mathrm{Cl}$

(a) 6-endo-Hydroxycineole dehydrogenase

$$
\begin{aligned}
& \text { Substrate } \\
& \text { Substrate specificity } \\
& \text { Electron acceptor } \\
& \text { pH optimum (ol } \rightarrow \text { one) } \\
& \text { pH optimum }(\text { one } \rightarrow \text { ol) } \\
& \text { Specific activity }(\text { ol } \rightarrow \text { one) } \\
& \text { 1,8-Cineole-grown } \\
& \text { Succinate-grown } \\
& \text { Specific activity (one } \rightarrow \text { ol) } \\
& \text { 1,8-Cineole-grown }
\end{aligned}
$$

(b) 6-Oxocineole oxygenase

Substrate
Substrate specificity*
pH optimum
Specific activity
1,8-Cineole-grown
Succinate-grown

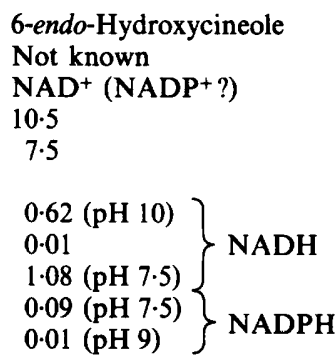

6-Oxocineole
Absolute?
9
$0.03-0.04$
0.001

* No significant activity with (+)-camphor, $(R)-(-)$-carvone, $(S)-(+)$-carvone, cyclohexanone, 1,3-cyclohexanedione, dihydrocarvone, 2-,3- and 4-methylcyclohexanone, fenchone, menthone, pinan-3-one, pulegone or verbenone. 
allowed a crude substrate stoichiometry $\left(\mathrm{O}_{2}: 6\right.$-oxocineole:NADPH) of $1: 0 \cdot 83: 0.90$ to be determined. Assays done in anaerobic Thunberg cuvettes as previously described (Donoghue $e t$ $a l ., 1976$ ) confirmed that NADPH oxidation was linked to oxygen consumption. GLC analysis of diethyl ether extracts of reactions with limited 6-oxocineole that had been allowed to run to completion at $\mathrm{pH} 9$ and adjusted to $\mathrm{pH} 1$ with $5 \mathrm{M}-\mathrm{HCl}$ before extraction showed that the 6-oxocineole had been converted into a single more polar metabolite (retention time $29 \mathrm{~min}$ ). GLC-MS analysis gave a spectrum - $m / e 166\left(37 \%, M-\mathrm{H}_{2} \mathrm{O}\right), 111(56 \%), 98(85 \%), 82(37 \%)$, $55(30 \%), 43(100 \%)$ - identical with that of the lactone $(R)-5,5$-dimethyl-4-(3'-oxobutyl)-4,5dihydrofuran-2(3H)-one isolated by MacRae et al. (1979) from culture medium of $P$. flava growing on 1,8-cineole. As the route whereby this lactone might arise from either 2-oxocineole (MacRae et al., 1979) or 6-oxocineole was not immediately apparent, attempts were made to purify 6-oxocineole oxygenase so that the initial oxygenation product could be isolated and identified.

\section{Stability and attempted purification of 6-oxocineole oxygenase}

Crude extract of 1,8-cineole-grown Rhodococcus $\mathrm{Cl}$, diluted to $4 \mathrm{mg}$ protein $\mathrm{ml}^{-1}$ in $42 \mathrm{~mm}-\mathrm{KH}_{2} \mathrm{PO}_{4} / \mathrm{Na}_{2} \mathrm{HPO}_{4}$ buffer (pH 7.1), lost all oxygenase activity when maintained at $4{ }^{\circ} \mathrm{C}$ for $24 \mathrm{~h}$. Reducing agents were not effective as stabilizers but addition of 5 or $10 \%(\mathrm{v} / \mathrm{v})$ ethanol to the buffer resulted in the loss of $<15 \%$ of the activity over the same time-period. Chromatography of $800 \mathrm{mg}$ of crude extract protein on a $2.5 \times 14 \mathrm{~cm}$ DEAE-Sephacel or DEAE-cellulose column, developed with a linear gradient $(700 \mathrm{ml}, 0-0.5 \mathrm{M}-\mathrm{KCl}$ in $42 \mathrm{mM}$ phosphate buffer, $\mathrm{pH} 7 \cdot 1$, containing $5 \%$, v/v, ethanol) separated the oxygenase from 6-endohydroxycineole dehydrogenase activities with 2.5 to 7 -fold increase in specific activity and $\simeq 40 \%$ recovery. All attempts at additional purification, including taking advantage of the short time scale allowed by FPLC, led to extremely poor recovery of enzyme units and a decrease in specific activity. When $15 \mathrm{mg}$ of partially purified enzyme (DEAE-cellulose or DEAE-sephacel stage), concentrated in an Amicon ultrafiltration cell, was incubated in a Warburg with $60 \mu \mathrm{mol}$ 6-oxocineole and an excess of NADPH in $\mathrm{H}_{3} \mathrm{PO}_{4} / \mathrm{Na}_{4} \mathrm{P}_{2} \mathrm{O}_{7}$ buffer ( $\mathrm{pH} 9$ ), $50 \mu \mathrm{mol}$ of oxygen were consumed. Direct ferric hydroxamate assay for the presence of lactones (Cain, 1961) showed them to be absent. However, when the remainder of the reaction mixture was acidified with $5 \mathrm{M}-\mathrm{HCl}$, followed by extraction of the product into diethyl ether, and a sample of this again tested (after removal of solvent) the positive response indicated the presence of a lactone. GLC analysis confirmed that this was the compound also obtained following the extraction of product formed by crude cell extract. GLC-MS analysis again gave a spectrum identical with that reported for the lactone $(R)-5,5$-dimethyl-4-(3'-oxobutyl)-4,5-dihydrofuran-2(3H)-one accumulated by $P$. flava (MacRae et al., 1979).

The cleavage of saturated cyclic ketones by micro-organisms is most frequently accomplished by biological Baeyer-Villiger oxygenation, followed by enzyme-mediated hydrolysis of the lactone thus formed (Trudgill, 1984, 1986). Since the lactone isolated from incubations of crude extract or partially purified 6-oxocineole oxygenase with NADPH and 6-oxocineole is a substituted 2-oxodihydrofuran (Fig. 1) and cannot be formed by direct oxygen insertion into the substrate it appears to be an artifact of the acidification and extraction procedure.

An investigation of the substrate specificity of the partially purified oxygenase, in which a wide range of cyclic and acyclic ketones was used, failed to reveal a single alternative substrate. This, unfortunately, excluded the exploitation of substrate analogues as investigative tools. In addition, our failure to purify the 6-oxocineole oxygenase to homogeneity necessitated an alternative approach to understanding the reaction sequence. This was sought on the working assumption that Baeyer-Villiger oxygenation was, nevertheless, the most likely initial step (Trudgill, 1984, 1986).

\section{Studies with 2,5-diketocamphane 1,2-monooxygenase from $P$. putida}

This Baeyer-Villiger monooxygenase has a broad ketone substrate specificity and initial trials with the partially purified enzyme from (+)-camphor-grown $P$. putida ATCC 17453 showed that oxygen consumption was stimulated by 6-oxocineole in the presence of NADH, the electron 
(i)<smiles>CC12CCC(CC1=O)C2(C)C</smiles>

(H)

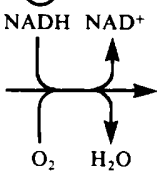<smiles>CC1(C)OC2CCC1(C)C2(C)C</smiles>

(ii)<smiles>CC12CC(=O)C(CC1=O)C2(C)C</smiles><smiles>C[C@@H]1C[C@@H]2C[C@H]1C2(C)C</smiles><smiles>CC12CC(=O)CC(CC(=O)O1)C2(C)C</smiles><smiles>[C+]CCCCCCCC</smiles><smiles>CC(C)(C)/C=C\C(=O)C1CCCC1</smiles>

(iii)<smiles>CC12CCC(C(=O)C1)C(C)(C)O2</smiles>

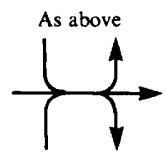<smiles>[2H]C1(C)OC2(C)CCCC1OC(=O)C2</smiles><smiles>CC(C)C(C)O</smiles><smiles>CC12CCC(CC1C(=O)O)C(C)(C)C(C)(C)O2</smiles><smiles>CC(=O)CC1CC(=O)OCC1C(C)(C)O</smiles>

Fig. 4. Reactions catalysed by 2,5-diketocamphane 1,2-monooxygenase from $P$. putida with (i) (+)-camphor and (ii) 2,5-diketocamphane as substrates. The proposed oxygenation reaction with 6-oxocineole as substrate (iii) is followed by the spontaneous cleavage of the oxygenation product (compound D) 1,6,6-trimethyl-2,7-dioxa(3,2,2)bicyclononan-3-one and the hemiacetal (compound E)

2,6,6-trimethyl-5-acetyltetrahydropyran-2-ol.

donor for this enzyme. Reactions in which 0.65 units of enzyme were incubated with $10 \mu \mathrm{mol} 6$ oxocineole and $15 \mu \mathrm{mol} \mathrm{NADH}$ in $42 \mathrm{~mm}-\mathrm{KH}_{2} \mathrm{PO}_{4} / \mathrm{Na}_{2} \mathrm{HPO}_{4}$ buffer $(\mathrm{pH} 7 \cdot 1$ ) were used for product accumulation and analysis. Direct hydroxamate assay for lactones showed them to be absent. However, acidification of the reaction mixture and diethyl ether extraction again generated a lactone which was identical with that formed with the crude and partially purified oxygenating system from 1,8-cineole-grown Rhodococcus $\mathrm{Cl}$.

This observation was of particular interest since (+)-camphor-grown $P$. putida does not produce a detectable lactone hydrolase (Taylor \& Trudgill, 1986). When either crude cell extract or the purified enzyme complex is incubated with $(+)$-camphor as ketonic substrate the stable 1,2-lactone accumulates. In contrast 2,5-diketocamphane yields an unstable lactone that spontaneously cleaves without enzymic assistance (Taylor \& Trudgill, 1986). The consequences of this, in terms of proton balance during the reaction, can be clearly observed in a $\mathrm{pH}$ stat. With $(+)$-camphor as substrate the proton consumed in oxygenation is not regenerated upon lactone cleavage and proton consumption can be followed. In contrast, oxygenation of 2,5diketocamphane is followed by spontaneous lactone cleavage, regeneration of a proton, and consequent maintenance of neutrality. When 6-oxocineole was used as substrate the preservation of near neutrality observed was also indicative of proton regeneration subsequent to oxygenation (Figs 4 and 5).

\section{Chemical Baeyer-Villiger oxygenation of 6-oxocineole}

6-Oxocineole $(15 \mathrm{mg})$ was incubated with $110 \mathrm{mg}$ magnesium monoperoxyphthalate in $5 \mathrm{ml}$ dimethylformamide for $16 \mathrm{~h}$ at $20^{\circ} \mathrm{C}$ followed by addition of $5 \mathrm{ml}$ of water and acidification. The product, extracted into diethyl ether, co-chromatographed with the detected reaction product of the biological Baeyer-Villiger oxygenation of 6-oxocineole and with the authentic lactone 5,5-dimethyl-4-(3'-oxobutyl)-4,5-dihydrofuran-2(3H)-one formed from $\alpha$-terpineol as described in Methods.

\section{DISCUSSION}

Other workers have reported that hydroxylation of 1,8-cineole either in preparation for ring cleavage (MacRae et al., 1979; Carman et al., 1986) or in non-assimilatory fermentation 


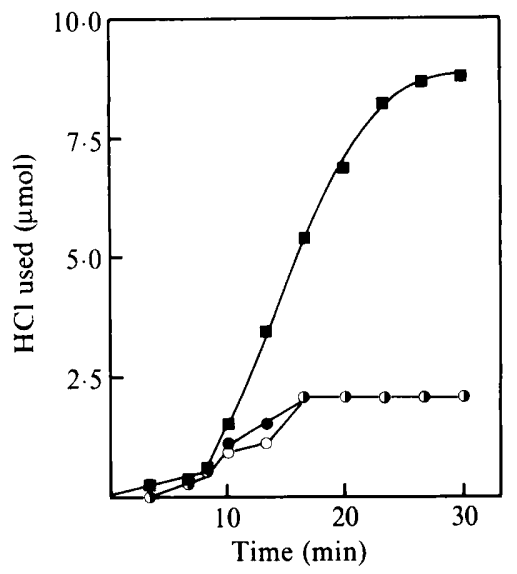

Fig. 5. A comparison of proton balance in the oxygenation of (+)-camphor, 2,5-diketocamphane and 6-oxocineole by partially purified 2,5-diketocamphane 1,2-monooxygenase from $P$. putida ATCC 17453 by $\mathrm{pH}$-stat assay. The stirred reaction vessel contained, in $11 \mathrm{ml}$ of distilled water (adjusted to $\mathrm{pH} 6.7$ by the addition of a minimum amount of $42 \mathrm{mM}-\mathrm{KH}_{2} \mathrm{PO}_{4} / \mathrm{Na}_{2} \mathrm{HPO}_{4}$ buffer), $10 \mu \mathrm{mol} \mathrm{NADH}$ and 0.5 units of oxygenase. The reaction $\mathrm{pH}$ was maintained at 6.7 by the controlled addition of $2 \mathrm{~mm}-\mathrm{HCl}$. After the establishment of endogenous rates $(8 \mathrm{~min})$ substrates $(10 \mu \mathrm{mol})$ were added and proton consumption measured by monitoring the controlled $2 \mathrm{mM}-\mathrm{HCl}$ additions required to maintain the preset $\mathrm{pH}$. $\mathbf{\square}$, camphor; 0 , 2,5-diketocamphane; $\mathrm{O}, 6$-oxocineole.

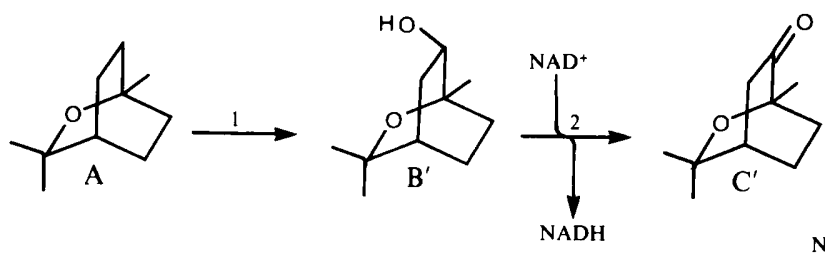

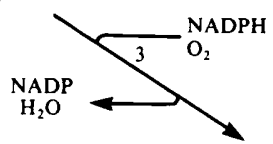<smiles>CC(=O)CCC1CC(=O)OC1(C)C</smiles><smiles>CC1(C)OC2(C(=O)[O-])CCC1C2(C)O</smiles><smiles>CC(C)C(C)O</smiles>

Fig. 6. Proposed ring cleavage reactions in the metabolism of 1,8-cineole by Rhodococcus $\mathrm{Cl}$. Compounds are (A) 1,8-cineole; ( $\mathrm{B}^{\prime}$ ) 6-endo-hydroxycineole; (C') 6-oxocineole; (D) 1,6,6-trimethyl-2,7dioxabicyclo(3,2,2)nonan-3-one; (E) 2,6,6-trimethyl-5-acetyltetrahydropyran-2-ol; (F) 3-(1-hydroxy-1methylethyl)-6-oxoheptanoic acid; (G) 5,5-dimethyl-4-(3'-oxobutyl)-4,5-dihydrofuran-2(3H)-one.

(Nishimura et al., 1982) involved attack exclusively at the C-2 and C-3 positions. Indeed, in our preliminary report (Taylor \& Trudgill, 1988) which was published before we obtained information on the optical rotation of the accumulated hydroxycineole and oxocineole we assumed, on the basis of ${ }^{1} \mathrm{H}-\mathrm{NMR}$ and mass spectral results, that this organism also attacked the terpene at the 2 position. It is of interest, but for no logical reason less likely, that Rhodococcus $\mathrm{C} 1$ initiates attack on 1,8-cineole at carbon-6. The proposed sequence of steps involved in the cleavage of 1,8-cineole is shown in Fig. 6. 
The reaction sequence has both commonplace and novel features. Initial hydroxylation of the terpene, although not demonstrated in cell-free systems, was clearly supported by metabolite accumulation studies and the induced dehydrogenation of 6-endo-hydroxycineole has been established. Our failure to detect this initial step is puzzling but not unique since a number of workers have been unable to demonstrate oxygenation steps in the initial activation of other terpene hydrocarbons (Griffiths et al., $1987 a$; Trudgill, 1984, 1986). The majority of identified biological Baeyer-Villiger monooxygenases are stable and relatively easy to purify. Unfortunately, the instability and apparent absolute specificity of the 6-oxocineole oxygenase made investigation of the detailed sequence of ring cleavage steps difficult. The observation that 2,5diketocamphane 1,2-monooxygenase from $P$. putida [a biological Baeyer-Villiger oxygenase that inserts a single atom of oxygen into $(+)$-camphor and related compounds between the ketonic carbon and the bridgehead] formed the same detected product provided strong circumstantial evidence that the oxygenase from strain $\mathrm{Cl}$ catalyses an identical reaction and (i) is a monooxygenase, (ii) catalyses a biological Baeyer-Villiger reaction and (iii) inserts an oxygen atom between the ketonic carbon and the adjacent carbon carrying a methyl group (Fig. 6). Other examples of alicyclic ketone metabolism in which biological Baeyer-Villiger oxygenation leads to the formation of an unstable lactone without a consequent requirement for a lactone hydrolase include 2,5-diketocamphane oxygenation, already mentioned, in which the presence of the second keto group initiates ring cleavage through loss of a proton from an adjacent carbon atom (Taylor \& Trudgill, 1986) and, more directly relevant to 1,8-cineole oxidation, hemiacetal formation by oxygenation of 2-hydroxycyclohexanone by an Acinetobacter sp. (Davey \& Trudgill, 1977). Spontaneous cleavage of the lactone 1,6,6-trimethyl-2,7dioxabicyclo $(3,2,2)$ nonan-3-one, which we propose as the immediate product of 6-oxocineole oxygenation, is a property of this very highly strained molecule and the spontaneous cleavage of the hemiacetal thus formed is a direct parallel to the spontaneous cleavage of other hemiacetals formed as intermediates in catabolic pathways (Bernhardt et al., 1973; Davey \& Trudgill, 1977), and yields the acyclic compound 3-(1-hydroxy-1-methylethyl)-6-oxoheptanoic acid. One of the characteristics of 4-hydroxy acids is the ease with which they form lactones in acid solution and dry solvents. Ring closure of the acid would yield the detected product of 2- or 6-oxocineole oxygenation: the respective isomer of 5,5-dimethyl-4-(3'-oxobutyl)-4,5-dihydrofuran-2(3H)-one. Indeed, precisely this spontaneous ring closure was exploited by Wallach (1895) in his investigation into the structure of $\alpha$-terpineol.

MacRae et al. (1979) established the absolute configuration of the lactone and other intermediates formed by $P$. flav $a$ and suggested that they were all derived by microbial oxidation at the same prochiral carbon of 1,8-cineole. Although we have not established the absolute configuration of 5,5-dimethyl-4-(3'-oxobutyl)-4,5-dihydrofuran-2(3H)-one formed by Rhodococcus $\mathrm{Cl}$ we have provided a logical explanation for its production. In principle, this sequence of ring cleavage reactions is also applicable to the other, less widely distributed and even more strained, natural isomer 1,4-cineole, with the parallel formation of the acyclic 3-hydroxy-(1methylethyl)-6-oxoheptanoic acid. In this context the recently reported formation of the 2-endohydroxy and 2-oxo derivatives as products of 1,4-cineole fermentation by a variety of bacteria and fungi grown in a rich medium is of interest (Rosazza et al., 1987).

The further metabolism of the acyclic catabolic intermediate of 1,8-cineole metabolism, 3-(1hydroxy-1-methylethyl)-6-oxohexanoic acid is currently under investigation. A mechanistically acceptable route for its degradation can be formulated in which levulinic acid and acetone are intermediates. In this context the ability of Rhodococcus $\mathrm{C} 1$ to grow with acetone as sole carbon source is of interest since the ability to utilize the compound is not universally distributed (Taylor et al., 1980).

We thank Dr Muriel Rhodes-Roberts and Dr M. Goodfellow for carrying out the identification of Rhodococcus sp. strain C1, Dr D. J. Hopper for checking the manuscript, Dr P. C. Harries for helpful advice and the Science and Engineering Research Council for a postgraduate studentship (D. R. W.). 


\section{REFERENCES}

Bernhardt, F.-H., Erdin, N., Staudinger, H. \& ULLRICH, V. (1973). Interaction of substrates with a purified 4-methoxybenzoate monooxygenase system (O-demethylating) from Pseudomonas putida. European Journal of Biochemistry 35, 601-611.

Best, D. J., Floyd, N. C., Magalhaes, A., Burfield, A. \& RHodes, P. M. (1987). Initial enzymatic steps in the degradation of alpha-pinene by Pseudomonas fluorescens NCIMB 11671. Biocatalysis 1, 147-159.

CAIN, R. B. (1961). The metabolism of protocatechuic acid by a Vibrio. Biochemical Journal 79, 298-312.

Carman, R. M., MacRae, I. C. \& Perkins, M. V. (1986). The oxidation of 1,8-cineole by Pseudomonas flava. Australian Journal of Chemistry 39, 1739-1746.

Chapman, P. J., Meerman, G., Gunsalus, I. C., SRinivasan, R. \& Rinehart, K. L. (1966). A new acyclic metabolite in camphor oxidation. Journal of the American Chemical Society 88, 618-619.

Davey, J. F. \& Trudgill, P. W. (1977). The metabolism of trans-cyclohexan-1,2-diol by an Acinetobacter species. European Journal of Biochemistry 74, 115-127.

DhavalikaR, R. S. \& Bhattacharyya, P. K. (1966). Microbial transformations of terpenes. VII. Fermentation of limonene by a soil Pseudomonad. Indian Journal of Biochemistry 3, 144-157.

Dhavalikar, R. S., Rangachari, P. N. \& BhattaCHARYYA, P. K. (1966). Microbial transformations of terpenes. IX. Pathways of degradation of limonene by a soil Pseudomonad. Indian Journal of Biochemistry 3, 158-164.

Donoghue, N. A., Norris, D. B. \& Trudgill, P. W. (1976). The purification and properties of cyclohexanone oxygenase from Nocardia globerula CL1 and Acinetobacter NCIB 9871. European Journal of Biochemistry 63, 175-192.

Friedemann, T. E. \& Haugen, G. E. (1943). Pyruvic acid. II. The determination of keto acids in blood and urine. Journal of Biological Chemistry 147, 415442.

Gornall, A. G., Bardawill, C. J. \& David, M. M. (1949). Determination of serum proteins by means of the biuret reaction. Journal of Biological Chemistry 177, 751-766.

Goodfellow, M. (1986). Genus Rhodococcus Zopf 1891, 28 AL. In Bergey's Manual of Systematic Bacteriology, vol. 2, pp. 1472-1481. Edited by P. H. A. Sneath, N. S. Mair \& M. E. Sharpe. Baltimore: Williams \& Wilkins.

Griffiths, E. T., Bociek, S. M., Harries, P. C., JeffCoat, R., Sissons, D. J. \& Trudgill, P. W. (1987a). Bacterial metabolism of $\alpha$-pinene: pathway from $\alpha$-pinene oxide to acyclic metabolites in Nocardia sp. strain P18.3. Journal of Bacteriology 169, 4972-4979.

Griffiths, E. T., Harries, P. C., Jeffcoat, R. \&
Trudgill, P. W. (1987b). Purification and properties of $\alpha$-pinene oxide lyase from Nocardia sp. strain P18.3. Journal of Bacteriology 169, 4980-4983.

Katagiri, M., Ganguli, B. N. \& Gunsalus, I. C. (1968). A soluble cytochrome P450 functional in methylene hydroxylation. Journal of Biological Chemistry 243, 3543-3546.

MacRae, I. C., Alberts, V., Carman, R. M. \& Shaw, I. M. (1979). Products of 1,8-cineole oxidation by a Pseudomonad. Australian Journal of Chemistry 32, 917-922.

Nishimura, H., Noma, Y. \& Mizutani, J. (1982). Eucalyptus as biomass. Novel compounds from microbial conversion of 1,8-cineole. Agricultural and Biological Chemistry 46, 2601-2604.

Ougham, H. J., Taylor, D. G. \& Trudgill, P. W. (1983). Camphor revisited: involvement of a unique monooxygenase in the metabolism of 2-oxo- $\Delta^{3}-4,5,5-$ trimethylcyclopentenylacetic acid by Pseudomonas putida. Journal of Bacteriology 153, 140-152.

Rosazza, J. P. N., Steffens, J. J., Sariaslani, F. S., Goswami, A., Beale, J. M., Reeg, S. \& Chapman, R. (1987). Microbial hydroxylation of 1,4-cineole. Applied and Environmental Microbiology 53, 24822486.

ROSENBERGER, R. F. \& ELSDEN, S. R. (1960). The yields of Streptococcus faecalis grown in continuous culture. Journal of General Microbiology 22, 726-739.

Shukla, O. P., Moholay, M. N. \& Bhattacharyya, P. K. (1968). Microbial transformations of terpenes. $X$. Fermentation of $\alpha$ - and $\beta$-pinenes in a soil pseudomonad (PL-strain). Indian Journal of Biochemistry 5, 79-91.

Taylor, D. G., Trudgill, P. W., Cripps, R. E. \& HARRIS, P. R. (1980). The microbial metabolism of acetone. Journal of General Microbiology 118, 159170.

Taylor, D. G. \& Trudgill, P. W. (1986). Camphor revisited: studies of 2,5-diketocamphane 1,2-monooxygenase from Pseudomonas putida ATCC 17453. Journal of Bacteriology 165, 489-497.

TAYlOR, D. G. \& Trudgill, P. W. (1988). The bacterial metabolism of 1,8-cineole (eucalyptol). In Microbial Metabolism and the Carbon Cycle, p. 510. Edited by S. R. Hagedorn, R. S. Hanson \& D. A. Kunz. Chur: Harwood.

TrudgiLl, P. W. (1984). Degradation of the alicyclic ring. In Microbial Degradation of Organic Compounds, pp. 131-180. Edited by D. T. Gibson. New York: Marcel Dekker.

Trudgill, P. W. (1986). Terpenoid metabolism by Pseudomonas. In The Bacteria, vol. 10, pp. 483-528. Edited by J. R. Sokatch. New York: Academic Press.

Wallach, O. (1895). Zur Constitutionsbestimmung des Terpineols. Chemische Berichte 28, 1755-1777. 